Finally, as to the aggregation and development of Bacteria about living Infusorians, this I have noticed in a colorless marine species, viz, Zoöthamnium alternans, and the same fact has been observed by Stein. Both Stein and myself have noticed Bacilli mostly in this relation to other living colorless Infusorians, but in the case of dead and colorless Infusorians the remains of the animals are usually attacked at one side and gradually invaded by Bacilli and Micrococci, and altogether independently of any peculiarly local oxygen-yielding source in the vicinity.

In conclusion it may be said that if there exist green Vorticellce which have the green coloring matter arranged diffusely in the ectoplasm in one species, and in another confined to distinct granules as observed in the species here described, it is fair to presume that, as in the cases of the three species of Stentor alluded to above, that we also have to do here with two very distinct species of Bell-animalcules. It is also fair to assume that if the different species present their coloring: matters in diverse conditions and modes of arrangement that such matters may have correspondingly different functions, and that it does not necessarily follow that the green granules even are a sure indication of the presence of true chlorophyll, though it may simulate that of the plant in its relation to the stratum of plasma covering the cell-wall. Why not suppose that some of these coloring matters of Infusorians have a function similar to hæmoglobin? It would, however, be much easier to suppose that the quasi-chlorophyll grains of $V$. chlorostigma were truly of the nature of chlorophyll than to assume as much regarding the diffuse green color as observed in the ectoplasm of a supposed variety or closely affiliated species of $V$. campanula, as has been done by Engelmann.

Washington, December 20, 1883.

\title{
A NEW GEOGRAPHICAL RACE OF THE MOUNTAIN SHEEP (OVIS MONTANA DALLI var. nov.) FROM ALASKA.
}

\section{By E, W. NELSON.}

During the course of my residence at Saint Michael's, Alaska, and subsequent travel along the Arctic coast of this Territory, between July, 1877, and September, 1881, hundreds of skins were seen of the Mountain Sheep, which I here designate as a new geographical race.

The types of the new race are two specimens brought me by Mr. L. N. McQuesten, a fur-trader living at Fort Reliance, on the Upper Yukon River, near the point where it crosses the British boundary line. These specimens were killed by the Indians on some mountains south of Fort Yukon, and on the west bank of the river.

From Mr. McQuesten, and various other fur traders along the Yukon and elsewhere, and $\mathrm{my}$ own observations, I learned that the range of 
this form covers nearly all the mainland of Alaska where there are mountains, excepting the vicinity of the Bering sea coast. It is limited strictly to the mainland and occurs only among the higher parts of the mountains south of about $68^{\circ}$ of latitude, but north of this it is found on lower ground, and as the mountains give place to low hills and rolling plains near the Arctic coast, it descends nearly or quite to the sea-level.

The southern limit is at present unknown, but is probably in about latitude $55^{\circ}$ and north nearly to $70^{\circ}$.

The Mountain Sheep found along the Lower Mackenzie River close to the Arctic coast, by Richardson, undoubtedly belong to this race, as do others found in the northern part of British America.

Among the natives I have seen typical skins from the mountains south of the Upper Kuskoquim River; from the headwaters of the Tanana; from the Kaviak Peninsula near Bering Straits; also from the mountains east and northeast of Kotzebue Sound, and, during the summer of 1881, while cruising between Kotzebue Sound and Point Barrow we saw hundreds of skins among the Eskimos, who invariably pointed to the low range of mountains a few miles back from the coast, when asked where the sheep were found.

While hunting near Cape Thompson, on the Arctic coast, the middle of July, 1881, I saw a pair of these animals within about five miles of the coast at an elevation of not over 300 feet above the sea. They were feeding on an open grassy plain at the foot of a series of low hills over which they ran the moment they caught wind of me, as I tried to ap. proach along the bed of a small gully. Among the skins seen by me I have been particularly struck by the uniformity in general coloration and appearance. In the present preliminary account only the most superficial peculiarities can be noticed owing to the writer's absence from Washington; but in a general list of Alaskan Mammals in preparation I hope to give fuller details.

\section{DESCRIPTION.}

\section{Ovis montana DaLLI var. nov. Northern Mountain Sheep.}

This form can be recognized at once by its nearly uniform dirty-white color, the light-colored rump area seen in typical montana being entirely uniform with the rest of the body in dalli. The dinginess of the white over the entire body and limbs appears to be almost entirely due to the ends of the hairs being commonly tipped with a dull rusty speck. On close examination this tipping of the hairs makes the fur look as though it had been slightly singed. This form also has smaller horns than its southern relatives, but how the two compare in general size and weight I am uable to say.

I name this form in honor of Mr. W. H. Dall, whose scientific work in Alaska is so well known.

Hamilton, New Mexico, December 22, 1883. 


\section{$2 \mathrm{BHL}$ Biodiversity Heritage Library}

Nelson, Edward William. 1884. "A new geographical race of the mountain sheep (Ovis montana dalli var. nov.) from Alaska." Proceedings of the United States National Museum 7(399), 12-13. https://doi.org/10.5479/si.00963801.399.12.

View This Item Online: https://www.biodiversitylibrary.org/item/31798

DOI: https://doi.org/10.5479/si.00963801.399.12

Permalink: https://www.biodiversitylibrary.org/partpdf/11538

\section{Holding Institution}

Smithsonian Libraries

\section{Sponsored by}

Smithsonian

\section{Copyright \& Reuse}

Copyright Status: NOT_IN_COPYRIGHT

This document was created from content at the Biodiversity Heritage Library, the world's largest open access digital library for biodiversity literature and archives. Visit BHL at https://www.biodiversitylibrary.org. 